Supplement of Hydrol. Earth Syst. Sci. Discuss., 11, 13207-13258, 2014

http://www.hydrol-earth-syst-sci-discuss.net/11/13207/2014/

doi:10.5194/hessd-11-13207-2014-supplement

(C) Author(s) 2014. CC Attribution 3.0 License.

(c) (1)

\title{
A global dataset of the extent of irrigated land from 1900 to 2005
}

\section{S. Siebert et al.}

Correspondence to: S. Siebert (s.siebert@uni-bonn.de) and M. Kummu (matti.kummu@aalto.fi) 


\section{Supplementary information:}

Supplements S1-S6 form the Historical Irrigation Dataset (HID) and are made available at an open data repository at https://mygeohub.org/publications/8. The recommended citation of the dataset is:

Siebert, S., Kummu, M., Porkka, M., Doell, P., Ramankutty, N., Scanlon, B. R. (2014). Historical Irrigation Dataset (HID), version 0.9, DOI: 10.13019/M2MW2G.

Supplement S1: Data sources for the subnational irrigation statistics used to develop the Historical Irrigation Dataset (HID) and methods used to fill data gaps in the statistics reported for each country and time step.

Supplement S2: Administrative unit ID used in the Historical Irrigation Dataset (HID) to link grid cells to subnational statistical units for each time step gridded to 5 arc-minute resolution.

Supplement S3: Area equipped for irrigation per subnational statistical unit (AEI_SU), country and world region used for each time step in the Historical Irrigation Dataset (HID).

Supplement S4: Illustration of the procedure to downscale AEI per subnational statistical unit (AEI_SU) to grid cells based on a detailed description of seven examples.

Supplement S5: AEI in the eight the gridded products of the Historical Irrigation Dataset (HID) for year 1900. The maps are presented at global scale and for two selected close-up areas, namely Western USA and South Asia.

Supplement S6: AEI in eight gridded products of the Historical Irrigation Dataset (HID) for years 1900, 1910, 1920, 1930, 1940, 1950, 1960, 1970, 1980, 1985, 1990, 1995, 2000, and 2005 at 5 arc-minute resolution. Data are provided as ascii-grids and in netcdf format. 